\title{
Determinants Transfer of Primary Business of Rice Farmers Household at Musi Rawas District South Sumatera Indonesia
}

\author{
Fifian Permata Sari ${ }^{1}$, Andy Mulyana ${ }^{1}$, Najib Asmani $^{1} \&$ Yunita $^{1}$ \\ ${ }^{1}$ Sriwijaya University, Palembang, South Sumatera, Indonesia \\ Correspondence: Priyono, Graduate Program Master of Management, Universitas Bina Darma, Palembang, \\ Indonesia. Tel: 81-21-697-4878. E-mail: priyono.unu_sidoarjo@yahoo.com
}

Received: March 21, 2017

Accepted: April 5, 2017

Online Published: April 24, 2017

doi:10.5539/res.v9n2p204

URL: http://doi.org/10.5539/res.v9n2p204

\begin{abstract}
Indonesia is a country whose majority lives of agriculture and food crop agriculture remains the livelihoods of the majority of the Indonesian population. South Sumatera province is one that is a center for food crops, especially rice. A district that has irrigation and a rice production center in South Sumatera is Musi Rawas District. In 10 years (1993-2013) recorded a decrease in the number of rice farmers households is significant in Indonesia, including in South Sumatera. Changes in the amount of rice farming households in the province of South Sumatera by Agricultural Census 2013 indicates the state of declining, even in the central areas of food. This situation is further interesting to study the determinants of primary business of rice farmers to plant non-food and non-agriculture, especially in the central areas of food and irrigated in South Sumatera, Indonesia. This study used survey method and logistic regression for the analysis data. The result shows that factors affecting farmers' decision to switch or not switch from the main businesses, namely rice farm to farm fish, rubber and non-agricultural businesses is land area, household income from rice, the income of non rice, grain price at farmers level, revenue from non paddy, costs of farming, commodity prices, employment opportunities outside of the main business, farming experience and knowledge of farmers on land conversion rules.
\end{abstract}

Keywords: determinant, primary business, farmer decision

\section{Introduction}

Countries whose economic growth mostly from agricultural products such as Indonesia, in general, is trying to develop itself from a situation and the nature of traditional society with the state of the economy backward toward a state that is considered better, grow and then into the broader economy advanced. The agricultural sector as a major contributor to the national income at the same time the largest absorber of labor available. With the success of such development, then gradually decrease the non-agricultural sector in contributing to national production and in providing employment (Suryadi, 2010).

Indonesia is a country whose majority lives of agriculture and food crop agriculture remains the livelihoods of the majority of the Indonesian population. Results of a complete enumeration of Agricultural Census 2013 according to BPS (2013), shows about the number of agricultural businesses in Indonesia as many as 26.13 million farming households, consisting of 5.49 thousand agricultural companies incorporated, and 6.17 other agricultural businesses. When compared with the situation 10 years earlier, however, the number of farming households in Indonesia decreased by 5.04 million households from 31.17 million in 2003 to 26.13 million households in 2013. This shows there has been a decline of farming households $1.75 \%$.

Indonesia suffered composition changes, especially in Java and outside Java. Based on the results of Agricultural Census 2003, there were $57.48 \%$ of farming households are in Java and the remaining $42.52 \%$ are outside Java. Meanwhile, according to the results of Agricultural Census 2013, the composition was $51.38 \%$ at $48.62 \%$ Java and outside Java. This suggests a reduction in the number of farming households amounted to $1.75 \%$ a year.

South Sumatra province is one that is a center for food crops, especially rice. A district that has irrigation and a rice production center in South Sumatra is Musi Rawas District. In 10 years (1993-2013) recorded a decrease in the number of rice farmers households is significant in Indonesia, including in this District. Changes in the amount of rice farming households in the province of South Sumatra by Agricultural Census 2013 indicates the state of declining, even in the central areas of food. Results of a complete enumeration of Agricultural Census 
2013 according to BPS (2014) when viewed from food crops such as rice, based on Official Statistics South Sumatra Province 40/07/16/Th.XVI, dated July 1, 2014, it is known that the number of households rice plants as much as 381.898 households. Household businesses rice plants are located mainly in Musi Rawas and the number of households Musi Rawas rice plant effort on Census of Agriculture in 2003 amounted to 41.823 households and declined in the Census of Agriculture 2013 to 22.517 households with a percentage decrease of 46.16 percent for 10 years. The decline of the rice farmers household can be described in Table 1 below:

Table 1. The amount of household farming food crops (rice), Census of Agriculture 2003 and 2013 in the province of South Sumatra

\begin{tabular}{|c|c|c|c|c|}
\hline \multirow{2}{*}{ No } & \multirow{2}{*}{ District/City } & \multicolumn{3}{|c|}{ Rice farmers household (person) } \\
\hline & & Census 2003 & Census 2013 & Change (\%) \\
\hline 1 & Musi Rawas & 41.823 & 22.517 & $-46,16$ \\
\hline 2 & OKI & 63.521 & 55.430 & $-12,74$ \\
\hline 3 & East OKU & 79.012 & 77.062 & $-2,47$ \\
\hline 4 & $\mathrm{OKU}$ & 16.497 & 8.238 & $-50,06$ \\
\hline 5 & South OKU & 21.530 & 19.588 & $-9,02$ \\
\hline 6 & Lahat & 25.152 & 24.373 & $-3,10$ \\
\hline 7 & Pagar Alam & 3.376 & 4.171 & 23,55 \\
\hline 8 & Muara Enim & 39.746 & 24.988 & $-37,13$ \\
\hline 9 & Prabumulih & 1.472 & 597 & $-59,47$ \\
\hline 10 & Palembang & 8.044 & 5.743 & $-28,61$ \\
\hline 11 & Empat Lawang & 15.116 & 13.271 & $-12,21$ \\
\hline 12 & Lubuk Linggau & 2.558 & 1.698 & $-33,63$ \\
\hline 13 & Ogan Ilir & 32.666 & 31.113 & $-12,74$ \\
\hline 14 & Banyuasin & 73.904 & 74.612 & 0,96 \\
\hline 15 & MUBA & 33.239 & 18.496 & $-44,35$ \\
\hline
\end{tabular}

Source: BPS of South Sumatera Indonesia, 2014.

Decreasing the number of rice farming households in Musi Rawas District which is the center of the rice crop in South Sumatera would be an interesting subject for further investigation. This is because the rice commodity is a very important sector in the economy of South Sumatera province. Agrarian characteristics inherent in this district, the longer it will increasingly shift when at a later decrease the number of farmer households continuously. There are at least two things that can explain the decline. First, the food crop farmers have switched to other sub-sectors more attractive and economical, for example, the plantation subsector. This was reflected in a surge in the number of households farming estates in the last 10 years. Agriculture Census in 2013 recorded a surge in oil palm growers, rubber, and cocoa respectively of 779.9 thousand households (100 percent), 1.2 million households (71.7 percent), and 286.3 thousand households (15.1 percent) during 2003-2013 (BPS, 2014). This situation is further interesting to study the determinants of primary business of rice farmers household to plant non-food and non-agriculture, especially in the central areas of food and irrigated in South Sumatera Indonesia.

\subsection{Objectives and Purposes}

The objectives of this research are:

1) How many percentage of farmer land switching function from the main business in Musi Rawas District, South Sumatera, Indonesia?

2) Factors affecting the rice farmers household switched to non-food and non-agricultural in Musi Rawas District, South Sumatera, Indonesia. 
The purpose of this study was to analyze the main determinants of farmer households over the business of the rice plant to non-food and non-agriculture in South Sumatra, Indonesia. Usefulness of research is important because it can contribute to solving the problem of farmer households shift from rice farming. Food sector particularly rice farming is a primary sector in South Sumatera, and also the largest contributor to the regional economy farmers who live from this sector.

\section{Research Method}

This study was conducted in South Sumatera Indonesia Location research done intentionally (purposive). This district is considering the centers of crop production in South Sumatera Indonesia, Musi Rawas District, and fed by irrigation. Agriculture Census of 2013, expressed on a decrease in the number of rice farming households in this districts. The experiment was conducted in 2015-2016.

The method used is a survey method in which samples are taken under consideration the representation of the characteristics of the phenomenon of population in Musi Rawas South Sumatera Indonesia. Data collected by the determination of farmer households that exist at the time of the study (2015) and has worked outside the main business and non-farm enterprises, whereas prior to rice farming. In this study will also be enumerated data on the factors that influence the shift of farming households from the main business off the main business and non-farm enterprises. The sampling method used is Disproportionated Stratified Random Sampling, where the population of farmers grouped into two categories or layers, i.e., 50 households that switched from main business to business non paddy and non-agricultural, and 50 household farmers who are still survive in the main business (paddy), over the last 10 years (2003-2013).

In accordance with the first goal, so to determine how many percentage of farmer land switching function from the main business in Musi Rawas District, South Sumatera, Indonesia explained descriptively. To answer the second purpose of research, about the factors that affect farm household businesses switch from rice farming to non-food farm and non-farm enterprises, used logistic regression with the following equation:

MBT $=\log (\mathrm{Pi})=\alpha_{1}+\beta_{1} \mathrm{LA}+\beta_{2} \mathrm{RFNP}+\beta_{3} \mathrm{RFNA}+\beta_{4} \mathrm{COF}+\beta_{5} \mathrm{CP}+1-\mathrm{Pi} \beta_{6} \mathrm{D}_{1}+\beta_{7} \mathrm{D}_{2}+\beta_{8} \mathrm{D}_{3}+\mu_{1}$

Where:

MBT=Main Business Transfer

$\mathrm{Pi}=$ Opportunity farmer households switch from main business

1-Pi=Opportunity farmer households for not switch from main business

LA $=$ Land Area (ha)

$\mathrm{RFNP}=$ Revenue from Non-Paddy (USD/yr)

RFNA=Revenue from Non-Agricultural businesses (USD/yr)

$\mathrm{COF}=$ Cost of Farming $(\mathrm{USD} / \mathrm{yr})$

$\mathrm{CP}=$ Commodity Prices

$\mathrm{D}_{1}=$ Dummy of employment opportunities outside of the main business

$\mathrm{D}_{2}=$ Dummy of farming experience

$\mathrm{D}_{3}=$ Dummy of knowledge of farmers land conversion rules

$\beta_{0}=$ Constant

$\beta_{1} \ldots \beta_{5}=$ Parameter alleged (coefficient)

\section{Result and Discussion}

\subsection{Performance of Rice Farmers Switched to Plant Non Food and Non Agriculture in Musi Rawas District,} South Sumatera Indonesia

In Musi Rawas, the majority of farmers who has a major effort in the form of rice farming irrigated fields of technical and semi-technical over the last 10 years (2003-2013) has been switched to rubber farming, fish farming and to the non-agricultural sector. It is also in line with the latest Agriculture Census, stating decline in the number of rice farming households in Musi Rawas, amounting to $46.16 \%$. Musi Rawas is a District were listed as the most widely District decreased the amount of rice farming households. Data paddy farming households in Musi Rawas according to BPS South Sumatera (2014) in 2003 showed a decline of 41,823 farming households, fell by 22,517 farming households in 2013 . 
Several District in Musi Rawas based on research showing that the majority of farmers have switched many major businesses are dominated by the District Tugumulyo, STL Terawas Ulu Ulu Lakitan or Middle Tribe Terawas and Muara Beliti. As in the District Tugumulyo average farmer switching to non-agricultural businesses. Along the main irrigation flow even in stark contrast seen between shop, home, shop, salon, garage, and only a few survived mapped fields. This is because of regional divisions that occurred in this district in 2007. A number of 17 Districts in Musi Rawas, has now increased to 21 districts and 277 villages.

Subdistrict Tugumulyo, from 1932 is the center of the rice in the district and is a pilot area irrigated rice. For that there are some zones that are currently maintained as a location of paddy fields in the village namely F. Mataram, despite the fact that there are still some who have switched functions. Currently the majority of the area of wetland in the District has been transformed into residential areas because of the expansion area, including offices and schools. The rest are fish ponds and rice fields. Likewise with Srikaton village is now dominated by settlements. This is because the population is increasing, so is the development of business and office space as a result of regional expansion in this area. Trade activities and services dominate the business people in this area. The emergence of restaurants, workshops, salons, Bimbel along the irrigation flow is an incredibly contrast today, although there are still some stretch of paddy fields.

STL Sub district and Muara Ulu Terawas Beliti dominated by a major effort to control rubber farming and partly to farm fish. Only in the village Sukaraya and Satan village Indah Jaya no farmers who switched from main business to non-agricultural sector. In the village of Satan Indah Jaya, the Water Village and Village Wukir Sari, the majority of farmers switch from rubber farming to the main business at 14 ha, 13.75 ha and 12.5 ha of the total area of land there. Condition rubber prices fell today makes farmers are also looking for a second job to supplement household income such as trade and became a laborer. Farmers who switch major effort to non-agricultural businesses in Musi Rawas have an average of less than one hectare of land. The narrowness of the land for rice farming was the main reason farmers to switch from the main business. Rather major effort in Musi Rawas can be seen in Table 2 below.

Table 2. Rather the main business district in South Sumatera, 2015

\begin{tabular}{|c|c|c|c|c|c|c|c|}
\hline No & District & Village & $\begin{array}{c}\text { Farmers Land } \\
\text { area (ha) }\end{array}$ & $\begin{array}{l}\text { Switch to fish } \\
\text { (ha) }\end{array}$ & $\begin{array}{l}\text { Switch to } \\
\text { rubber (ha) }\end{array}$ & $\begin{array}{l}\text { Switch to non } \\
\text { agriculture (ha) }\end{array}$ & $\begin{array}{c}\text { Switch } \\
\text { percentage }(\%)\end{array}$ \\
\hline \multirow[t]{3}{*}{1} & Tugumulyo & Srikaton & 102 & 0 & 5 & 7,5 & 12,25 \\
\hline & & Wukir Sari & 125 & 14 & 12,5 & 2 & 22,80 \\
\hline & & Sukaraya & 93 & 7,5 & 10 & 0 & 18,81 \\
\hline \multirow[t]{3}{*}{2} & $\begin{array}{l}\text { STL Ulu } \\
\text { Terawas }\end{array}$ & Sukaraya Baru & 110 & 11,75 & 12,25 & 3 & 24,54 \\
\hline & & Terawas & 117 & 5,25 & 11,5 & 10 & 22,86 \\
\hline & & Ketuan Jaya & 105 & 12 & 6 & 5,5 & 22,38 \\
\hline \multirow[t]{4}{*}{3} & Muara Beliti & Air Lesing & 95 & 7 & 13,75 & 7,25 & 29,47 \\
\hline & & Satan Indah Jaya & 84 & 12,5 & 14 & 0 & 31,54 \\
\hline & \multicolumn{2}{|c|}{ Total } & 831 & 70 & 85 & 35,25 & 190,25 \\
\hline & \multicolumn{2}{|c|}{ Average } & & $8,42 \%$ & $10,22 \%$ & $4,24 \%$ & $22,89 \%$ \\
\hline
\end{tabular}

Source: Primary data is processed (2015).

Table 2 shows that in the District Tugumulyo, District STL Ulu Beliti Terawas and Muara District, the average area of land are turning to fish farming as much as $8.42 \%$ of the total land area in the three sub-districts. While the average rice field area turned usatani rubber amounted to $10.22 \%$ and switch to non-agricultural sector amounted to $4.24 \%$. The village which dominates over the main effort to the fish farm is in the village of West Sukaraya 11.75 ha. Desa Water lecture Kecamata Muara Beliti majority of farmers turning to rubber farming's main business is as much as 13.75 ha and for the District Tugumulyo majority switching to non-agricultural sector in Desa Srikaton of 7.5 ha. Farmer households in Musi Rawas main businesses are turning to non-agricultural businesses on average for wetland has been fragmented or in the form of a narrow field, so that farmers are not keen to cultivate rice. The reason farmers in addition to the narrow area of land, the costs incurred for rice farming is not comparable with the results obtained. Some farmers finally switch to the trading 
businesses and services and some of them decided to sell the land. Land sold for an average of a narrow field, and eventually founded the home or shop, food stalls, salons and workshops. This phenomenon is reinforced by the results of research Hartoyo (1994) which showed that the narrow area of land controlled by farming households, then the lower the percentage of household income comes from agriculture. This shows that there is a linear relation between the area of land ownership by the amount of income received by the farmer households.

3.2 Determinant of Rice Farmers Household not Switched to Non Food and Non Agriculture Business at Musi Rawas District, South Sumatera, Indonesia

There are several determinants of farm households not switched from paddy or main business, were comprised of land area, household income from rice, the income of non-rice and grain prices at the farmers level. Based on the statistical test known Omnibus sig= 0.000 or less than 0.05 , which means the rules of the decision reject $\mathrm{H}_{0}$. This means $\mathrm{G}_{2}$ (overall model test results) was $46.3 \mathrm{p}$ value of 0.000 means there is at least one independent variables that affect the dependent with a confidence level of $90 \%$ so this means that the model can be used for further analysis. Based on the statistical test known Omnibus sig $=0.000$ or less than 0.05 , which means the rules of the decision reject $\mathrm{H}_{0}$. This means $\mathrm{G}_{2}$ (overall model test results) was $46.3 \mathrm{p}$ value of 0.000 means there is at least one independent variables that affect the dependent with a confidence level of $90 \%$ so this means that the model can be used for further analysis.

Test results Nagelkerke $\left(\mathrm{R}^{2}\right)$ illustrates the value of determination coefficient of $84 \%$, which means that the level variations of the model can be described jointly by the explanatory variable in the model by $84 \%$ and the remaining $16 \%$ is explained by other variables outside the model. Meanwhile Hosmer and Lemeshow test results demonstrate the value of output $\mathrm{sig}=0.412$ greater than 0.05 , which means the decision accept $\mathrm{H}_{0}$. In conclusion logistic regression model that is used to describe the data with $90 \%$ confidence level. While the partial test results (Table 3) showed a significant variable at the level of up to $30 \%$ is a variable land area (1.2\%), household income from rice $(1.3 \%)$, the income of non-rice $(21.5 \%)$ and the grain price at the farmers level $(15.6 \%)$.

Table 3. Results of the logit regression for the decision of rice farmers not switched to non food and non agriculture business in Musi Rawas District of South Sumatera Indonesia

\begin{tabular}{ccccccc}
\hline No & Variable & B & S.E & Wald & Sig & Exp (B) \\
\hline & Constants & 52,754 & $1,688 \mathrm{E} 4$ & 0,000 & 0,900 & $2,304 \mathrm{E} 23$ \\
1 & Land area & $-8,216$ & 3,574 & 5,342 & $* * 0,012$ & $1,104 \mathrm{E} 4$ \\
2 & Household income from rice & $-0,002$ & 0,002 & 1,466 & $* * * 0,013$ & 0,987 \\
3 & The income of non-rice & 0,000 & 0,000 & 5,776 & $* * 0,215$ & 1,000 \\
4 & Grain price at the farmers & $-0,000$ & 0,000 & 2,100 & $* * 0,156$ & 1,000 \\
\hline
\end{tabular}

Source: Primary data is processed (2015).

$$
\begin{aligned}
& \text { Where: * significant at } \alpha=10 \% \\
& * * \text { significant at } \alpha=20 \% \\
& * * * \text { significant at } \alpha=30 \% \\
& * * * * \text { not significant }
\end{aligned}
$$

Farm household decision not to switch from the main business exhibited significantly influenced by the following explanatory variables.

\subsection{Land Area}

The land area significantly influence farm household decision to switch from main business (paddy) at the level of $1.2 \%$ with a negative direction. This indicates that the narrower the procurement of land, the possibility of farming households to switch from the main business will increase. This is also supported by the results of Odds ratio (Exp.B) of 1,104E4 which showed that the total area of land holdings owned by farmers, the tendency of farmers not to switch from rice farming. According to Munajat and Sari research (2014), one of the factors that influence the decision of rice farmers in working outside of agriculture sector because of lack of land tenure for farmers, but it is also influenced by factors family income and number of family members. In line with this, 
Sugiarto (2008) states that the contributing role of off-farm income sources higher in the group of the narrow land tenure and otherwise contributing role off-farm income was lower with the wider tenure.

\subsection{Household Income from Rice}

Variable household income from rice significantly affect the level of $1.3 \%$ with a negative direction. This is an indication that the lower the household income of farmers of rice farming households will increase the chances of farmers to switch from the main business.

\subsection{The Income of Non-Rice}

Variable income of non-rice in this case a fish pond, rubber and non-agricultural sector. Significantly affect the level of $21.5 \%$ with a positive direction. This is an indication that the increase of the income of non-rice will increase the chances of farmer households to switch from the main business. Munajat (2012), in his empirical study states that alternative look for another job (side) had to do household rice farmers, because with a very narrow area several times due to the ongoing fragmentation. The result of agricultural activities that do not provide for a decent life for farmers and households.

\subsection{Grain Prices at the Farmers Level}

Variable grain prices at the farmers level is based on the analysis affect significantly the level of $15.6 \%$ with a negative direction. This indicates that the lower the price of grain at the farm level, the decision farming households to switch from rice farming will increase.

3.7 Determinant of Rice Farmers Household Swithed to Non Food and Non Agriculture Business at Musi Rawas District, South Sumatera, Indonesia

Based on the results of statistical tests Omnibus known that sig $=0.000$ which is less than 0.05 , which means the rules of the decision was rejected Ho. This means $\mathrm{G}_{2}$ or test results of the overall model is 46.3 with a p-value 0.0000 which means that there is at least one independent variables that affect the dependent variable with a confidence level of $95 \%$. This means that the model can be used for further analysis. The test results Nagekelke $\mathrm{R}^{2}$ depicting koefrisien determination value by $76 \%$ with the level variations of the model can be described jointly by the explanatory variable in the model by $76 \%$ and the remaining $24 \%$ is explained by the explanatory variables outside the model.

Hosmer and Lemeshow test result shows the output $\operatorname{sig}=0,518$ greater than 0.05 , which means the results received Ho. In conclusion, the logistic regression model was used to explain the data with $95 \%$ confidence level. Partial assay results in Table 4 shows that significant efforts over the main farm household in Musi Rawas is a variable area $(5.2 \%)$, variable income from non rice $(28 \%)$ and variable commodity prices $(9.8 \%)$.

Table 4. Results of the logit regression for the decision of rice farmers switched to non food and non agriculture business in Musi Rawas District of South Sumatera Indonesia

\begin{tabular}{|c|c|c|c|c|c|c|}
\hline No & Variable & B & S.E & Wald & Sig & $\operatorname{Exp}(\mathrm{B})$ \\
\hline & Constant & 7,203 & 3,525 & 5,489 & 0,010 & $3,708 \mathrm{E} 3$ \\
\hline 1 & Land area & 0,005 & 0,013 & 0,146 & 0,762 & 0,985 \\
\hline 2 & Revenue from non paddy & 0,000 & 0,000 & 0,004 & 0,972 & 1,000 \\
\hline 3 & Cost of farming & $-0,549$ & 2,821 & 0,032 & 0.754 & 0,573 \\
\hline 4 & Commodity price & 0,000 & 0,000 & 1,155 & $* * * 0,270$ & 1,000 \\
\hline 5 & $\begin{array}{l}\text { Employment opportunities outside } \\
\text { of the main business }\end{array}$ & $-2,737$ & 1,353 & 3,766 & $* 0,054$ & 0,048 \\
\hline 6 & Farming experience & $-2,694$ & 1,709 & 2,631 & $* 0,097$ & 0,050 \\
\hline 7 & $\begin{array}{l}\text { Knowledge of farmers land } \\
\text { conversion rules }\end{array}$ & $-0,010$ & 1,406 & 0,000 & 0,985 & 0,970 \\
\hline
\end{tabular}

Source: Primary data is processed (2015).

$$
\begin{aligned}
& \text { Where: *significant at } \alpha=10 \% \\
& * * \text { significant at } \alpha=20 \% \\
& * * * \text { significant at } \alpha=30 \% \\
& * * * * \text { not significant }
\end{aligned}
$$


Farm household decision switched from the main business exhibited significantly influenced by the following explanatory variables.

\subsection{Commodity Price}

The commodity price is significantly influence farm household decision to switch from main business (paddy) at the level of $27.0 \%$ with a positive direction. This indicates that the higher of the commodity price, the possibility of farming households to switch from the main business will increase.

\subsection{Employment Opportunities Outside of the Main Business}

Variable employment opportunities outside of the main business significantly affect the level of $5.4 \%$ with a negative direction. This is an indication that the higher employment opportunities outside of the main business will increase the chances of farmer households to switch from the main business.

\subsection{Farming Experience}

Farming experience variables in this case, significantly affect the level of $9.7 \%$ with a negative direction. This is an indication that the lower of farming experience will increase the chances of farmer households to switch from main business or rice farming.

\section{Conclusion}

Based on the research results the farmer's decision to not switch from primary or rice farming business is significantly affected by land area, household income from rice, the income from non rice, and the grain prices at the farmers level. While the factors that significantly affect farming households switch from paddy farming is commodity prices, the employment opportunities outside of the main business, and farming experiences.

\subsection{Suggestion}

Advised the government to tighten laws on land use in food centers that function Musi Rawas South Sumatra as one of the centers of food in Indonesia can still be maintained.

\section{References}

BPS. (2013). Census of Agriculture results. Central Bureau of Statistics, Jakarta.

BPS. (2014). South Sumatera in 2014. The Central Bureau of Statistics, South Sumatera.

BPS South Sumatera. (2014). South Sumatera in Figures 2014. Central Bureau of Statistics, Palembang.

Munajat. (2012). Behavioral Analysis Paddy Farmers in the Use Input Rice Post-occurrence of Land Fragmentation on Rice Center in East Ulu Ogan Ogan. Proceedings of the National Seminar PERHEPI UNSRI, Indralaya.

Munajat, \& Sari, F. (2014). Determinant Decision and Strategies for Increasing Income Farmers After Land Fragmentation at East OKU Regency. Proceeding of International Conference, Medan.

Sugiarto. (2008). Analysis of Income, Consumption and Welfare of Farmers Rice on base Agroekosistem Wetland in Rural Irrigation. Centre Socio Economic and Policy Department of Agriculture, Bogor.

Suryadi. (2010). Growth and Development of Agricultural Economics. Institute of Agriculture, Bogor.

\section{Copyrights}

Copyright for this article is retained by the author(s), with first publication rights granted to the journal.

This is an open-access article distributed under the terms and conditions of the Creative Commons Attribution license (http://creativecommons.org/licenses/by/4.0/). 